\title{
Financing Mechanism for Operating and Investment Activities in Agriculture of Russia
}

\author{
Inna Boldyreva ${ }^{1, *} V^{1 k}$ toriya Tinyakova ${ }^{2}$ Yekaterina Alpatova ${ }^{1}$ \\ Elmira Zhusipova ${ }^{4}$
}

\author{
${ }^{1}$ Don State Agrarian University, Novocherkassk, Rostov Region, Russian Federation \\ ${ }^{2}$ State University of Management, Moscow, Russian Federation \\ ${ }^{3}$ Don State Technical University, Rostov-on-Don, Russian Federation \\ ${ }^{4}$ South Kazakhstan State University, Shymkent, Kazakhstan \\ *Corresponding author. Email: inbold@rambler.ru
}

\begin{abstract}
The article outlines conceptual foundations, features and contradictions of the financial mechanism of agricultural enterprise functioning. Global problems of financial support for the agricultural business, as well as specific financial problems of agricultural enterprises in Russia are identified. Analysis of the main financial indicators of agricultural enterprises of the Russian Federation is carried out, which reveals significant annual fluctuations in the financial results of enterprises, a significant differentiation in the level of profitability of livestock and crop production, dependence of the operating and investment activities of the agricultural sector on external funding sources, an insignificant contribution of state into the financial support of agricultural sphere. Systemic measures for optimizing the state financial support mechanism for agriculture in the context of individual instruments (budget, credit, and tax) are proposed.
\end{abstract}

Keywords: agriculture, reproduction, finance, investment, credit, leasing, government support

\section{INTRODUCTION}

Ensuring the competitive advantages of agriculture in any country is largely determined by the financial conditions for agricultural production, both in terms of operating activities and in relation to the development of reproduction processes.

Due to a high-risk nature, agricultural production has specific features of formation of financial resources, arrangement of financial relations, and implementation of investment activities. In this regard, in most countries of the world this sector of the economy operates in the context of state financial support.

Studying the problems of financial support for the agricultural sector, we can distinguish a number of problems, both international in nature and specific to individual countries.

The general problems of agricultural production, affecting the forms, methods and tools of financial support include:

- significant capital intensity due to a long period of working capital turnover;

- unpredictability of financial results due to a seasonal nature of the activity, biological and natural-climatic reasons;

- mismatch of the operational and financial cycle, leading to significant cash gaps.

The specific problems of financial support of farming operations in the Russian Federation are:
- price disparity between agricultural and industrial products in favor of the latter;

- presence of a barter form of payment for products;

- strict restrictive criteria for obtaining budget subsidies in the form of compulsory insurance;

- high bank loan rates, and, as a consequence, possibility of lending only at the expense of soft budget loans and consumer cooperation loans.

Thus, the features of the financial mechanism for carrying out activities in the agricultural sector are manifested in almost all of its elements: in the system of financing and lending, methods of managing financial resources, directions for their use, a set of financial levers, tools, and regulators.

\section{REVIEW OF LITERATURE ON RESEARCH ISSUE}

Models, methods, tools and forms of organizing financial relations in the agricultural sector are the subject of scientific research by scientists and economists in many countries.

A global post-Marxist approach to address financing of agricultural development used by V. Son, Ch. Schinckus, and F. Chong allows to explore the potential of agriculture in rural development, its impact on regional consumption and economy as a whole and consider the agricultural sector as an engine of economic growth even for developing countries [1]. 
The problems of financing operational and investment activities in the agricultural sector, studied in a narrower format, can be systematized as follows:

- financing models of sustainable agriculture in the context of climate change [2-4];

- methods of organizing and financing supply chains in the procurement of agricultural products [5-7];

- specific financing instruments for large, medium and small businesses in agriculture in developing countries [810];

- ways to overcome the crisis of agricultural enterprises in developed countries [11-12];

- mechanisms of state financial support for agriculture in developed and developing countries [13-18].

The aim of this work is a comprehensive systematic study of the financial mechanism of functioning of agricultural enterprises of the Russian Federation, taking into account the specific characteristics described above.

Achievement of this goal required a number of successive tasks:

- studies of general parameters of the financial state of enterprises in the agricultural sector (financial result of operations, the share of unprofitable enterprises, indicators of receivables and payables, profitability of products, volume of investments);

- examination of the structure and dynamics of funding sources of investments in the agricultural sector;

- systematization and analysis of the forms and volumes of state financial support for agriculture;

- identifying the degree of influence of state financial support on the level of profitability of certain types of activities of agricultural enterprises.

\section{MATERIALS, METHODS AND RESULTS}

The use of statistical analysis methods helps to identify features and trends in the implementation of financial support, both in the operational activities of agricultural enterprises and in the implementation of investment processes in agriculture.
As an empirical base of the study, the official data of the Federal State Statistics Service of Russia are used.

Currently, the agrarian sector of the Russian economy is the largest intersectoral complex, uniting more than 10 areas of activity focused on the production and processing of agricultural raw materials. The effectiveness of agriculture directly affects 38 million inhabitants of rural territories (or $26 \%$ of the total population of the Russian Federation) providing the activities of more than 17 million various agricultural associations, organizations, enterprises, farms (peasants) and private farms in more than 150 thousand rural areas.

At the same time, the contribution of agriculture to the gross added value in the Russian Federation during the period from 2002 to 2014 steadily decreased from 6 to 4\% [19]. In 2015 , for the first time in the last decade, there was an increase in the share of agriculture in the gross added value, prevailing in the whole economy of the Russian Federation, which amounted to $4.4 \%$. Against the background of a general drop in the index of output of goods and services by economy, agriculture became almost the only industry in which the growth rate of production was observed.

It should be noted that the functioning of agricultural production in Russia in 2012-2014 was carried out under the influence of two measures of state foreign trade policy that were differently oriented in terms of goals and effectiveness:

- on the one hand, entry into the WTO (2012), which led to even greater opening of food markets for cheap imported products;

- on the other hand, introduction of a food embargo on imports of agricultural products and food products from the EU and the USA (2014).

In this regard, it seems appropriate to consider statistical data on the financial performance of enterprises of the agricultural sector of the Russian Federation since the introduction of the food embargo on imports, which made it possible for Russian agricultural producers to plan their operational and investment activities in conditions of low competition with imported agricultural products (Table 1).

Table 1. Dynamics of financial indicators of agricultural enterprises of the Russian Federation [20]

\begin{tabular}{|l|c|c|c|c|c|}
\hline \multicolumn{1}{|c|}{ Indicator } & $\mathbf{2 0 1 4}$ & $\mathbf{2 0 1 5}$ & $\mathbf{2 0 1 6}$ & $\mathbf{2 0 1 7}$ & $\mathbf{2 0 1 8}$ \\
\hline $\begin{array}{l}\text { Balanced financial result (profit minus loss) of organizations, in billions } \\
\text { of rubles }\end{array}$ & 181.1 & 265.3 & 240.8 & 171.5 & 206.2 \\
\hline Share of profitable organizations in the total number of organizations, \% & 73.6 & 77.0 & 77.7 & 75.6 & 73.8 \\
\hline - in crop production & 20.2 & 35.4 & 30.3 & 17.2 & 20.6 \\
\hline - in livestock farming & 18.3 & 15.4 & 9.8 & 12.0 & 12.8 \\
\hline Accounts payable, in billions of rubles & 428.9 & 535.7 & 528.2 & 518.7 & 548.7 \\
\hline including overdue & 22.1 & 21.7 & 20.6 & 16.3 & 21.0 \\
\hline Loan debt, in billions of rubles & 1260.9 & 1420.9 & 1477.1 & 1413.6 & 1692.7 \\
\hline Accounts receivable, in billions of rubles & 449.6 & 568.3 & 587.6 & 571.4 & 696.3 \\
\hline$\quad$ including overdue & 13.2 & 12.9 & 13.1 & 12.6 & 13.5 \\
\hline $\begin{array}{l}\text { Investments in fixed assets aimed at the development of agricultural } \\
\text { organizations, in billions of rubles }\end{array}$ & 313.8 & 304.7 & 379.8 & 400.5 & 431.8 \\
\hline
\end{tabular}


The data presented in Table 1 indicate that in the reporting period from 2014 to 2018 there is an abrupt change in the balanced financial result (profit) of the activities of agricultural enterprises. This trend indicates volatility of revenue and unpredictability of financial results of agricultural enterprises, which complicates planning of operating and investment activities.

Nevertheless, there is a tendency to increase investments in agriculture, as evidenced by data on growth of investment in fixed assets by $37 \%$ for the period under review. Moreover, the investment volume is 2 times higher than the volume of own sources of financing (profit), which indicates the attraction of a significant amount of borrowed and external funds for investment purposes. This fact is confirmed by the growing volume of bank loan debt, especially in 2018. At the same time, a comparison of the amount of bank loan debt (1,692.7 billion rubles), the financial result of agricultural enterprises (206.2 billion rubles) and the amount of investments ( 431.8 billion rubles) in 2018 indicates that most of the borrowed funds are used not for investment purposes, but for the implementation of current operating activities, which indicates the presence of financial instability and high financial risks.

Peculiarities of the investment mechanism in agriculture are:

- long payback period;

- possibility of accumulation of own funds of enterprises due to low tax burden on profits;

- difficulty of accumulating depreciation deductions due to the high degree of depreciation of fixed assets;

- attractiveness of leasing as an instrument of borrowed financing in comparison with lending.

The data in Table 2 allow to assess the scale of investment activity in agriculture and the proportions of the volumes of financing attracted for investment purposes from domestic and borrowed sources. The share of attracted funds for the financing of investments in fixed assets aimed at the development of agriculture for the period from 2015 to 2018 increased from 41 to $48 \%$ in the structure of sources of financing investments.

Table 2. Financial sources for investments in fixed assets aimed at the development of agriculture

\begin{tabular}{|l|c|c|c|c|}
\multicolumn{1}{|c|}{ Indicator } & $\mathbf{2 0 1 5}$ & $\mathbf{2 0 1 6}$ & $\mathbf{2 0 1 7}$ & $\mathbf{2 0 1 8}$ \\
\hline Investments in fixed assets, total & 304.7 & 379.8 & 400.5 & 431.8 \\
\hline $\begin{array}{l}\text { including: } \\
\text { - own funds of enterprises }\end{array}$ & 180.3 & 222.4 & 225.4 & 224.9 \\
\hline - external funds & 124.4 & 157.4 & 175.1 & 206.9 \\
\hline $\begin{array}{l}\text { including: } \\
\text { budget resources }\end{array}$ & 5.5 & 9.4 & & \\
\hline $\begin{array}{l}\text { including: } \\
\text { - federal budget funds }\end{array}$ & 2.1 & 4.3 & 9.4 \\
\hline $\begin{array}{l}\text { - funds of budgets of constituent entities of the Russian } \\
\text { Federation }\end{array}$ & 3.2 & 4.7 & 4.6 & 4.4 \\
\hline - local budget funds & 0.2 & 0.1 & & 4.2 \\
\hline
\end{tabular}

Describing the external borrowing sources of agricultural producers, it should be noted that large businesses operating in agriculture, as an external source of investment, to a greater extent use bank credit, cheapened by subsidizing the interest rate by the state. Small businesses are less able to attract preferential bank loans and, as a rule, use leasing operations as the main source of external borrowing for investment purposes.

Moreover, as can be seen from the data in Table 2, in general, the volume of state financial support for investment activity in agriculture is insignificant and does not significantly affect the development of investment processes in the industry.

A study of the features of the mechanism of state support for the agricultural sector in Russia, the USA and EU countries shows the presence of significant differences not only in the cost proportions of state aid, but also in the forms and methods of support. Thus, the US government support system for agriculture is mostly characterized by indirect methods and unrelated forms of support; in Russia, state financial support is usually provided by direct methods and in a connected form (for example, state subsidizing of the interest rate on loans received by agricultural producers in commercial banks) [13.14].

The mechanism of state financial support for agricultural producers in the Russian Federation should be analyzed in more detail. On the one hand, by joining the World Trade Organization, Russia assumed obligations to reduce budget subsidies for agriculture, and on the other hand, the implementation of import substitution policies in the food sector is impossible without systemic state financial support. Direct subsidization of agriculture is carried out in almost all economically developed countries, but the level and structure of subsidies are different. The largest share of direct payments in the structure of expenditures for agricultural support is noted in Norway, Australia, the USA and the countries of the European Union [15].

Per 1 hectare of agricultural land, the largest support for rural producers is provided in the EU - \$637.1, in the US - \$ 190 [16]. Among the countries of the Customs Union, specific indicators show that agriculture is least supported in the Russian Federation - $\$ 78.5$ per 1 hectare of sown area.

The largest specific indicators of support are observed in the Republic of Belarus - 471.1 dollars per 1 hectare, in the Republic of Kazakhstan - 87.3 dollars per 1 hectare [17]. 
Table 3. Multi-layer structure of state financial support for agriculture

\begin{tabular}{|c|c|}
\hline $\begin{array}{c}\text { Level of state financial } \\
\text { support }\end{array}$ & State financial support tools \\
\hline Federal level & $\begin{array}{l}\text { - preferential tax treatment for agricultural producers (Unified Agricultural Tax); } \\
\text { - subsidizing the interest rates of investment and short-term loans for agricultural } \\
\text { producers; } \\
\text { - decoupled support }\end{array}$ \\
\hline $\begin{array}{l}\text { Level of the constituent entity of } \\
\text { RF }\end{array}$ & $\begin{array}{l}\text { - reimbursement of partial costs of agricultural producers for replenishment of fixed } \\
\text { and circulating assets; } \\
\text { - subsidizing the loan interest rates for agricultural producers; } \\
\text { - reimbursement of partial costs of paying insurance premiums under agricultural } \\
\text { insurance contracts; } \\
\text { - leasing of agricultural machinery and breeding animals using budget funds; } \\
\text { - support of economically significant agricultural development programs of the } \\
\text { constituent entities of the Russian Federation. }\end{array}$ \\
\hline Municipal level & - subsidized loan interest rates for agricultural producers \\
\hline
\end{tabular}

The main items of agricultural financing from the federal budget of the Russian Federation in the last few years are:

- partial reimbursement of the interest rate on investment loans (borrowings) for the development of animal husbandry and crop production, processing and development of infrastructure and logistics for product markets of these sub-sectors;

- partial reimbursement of the interest rate on short-term loans (borrowings) for the development of crop production and animal husbandry, processing and sales of products of these sub-sectors;

- providing decoupled support in crop production.

About $50 \%$ of the allocated funds falls on the partial reimbursement of the interest rate on loans (borrowings). Decoupled financial support accounts for $15-20 \%$ of the federal budget expenditure on agriculture.

Assessing the conditions for provision of budgetary subsidies to agricultural producers, one should recognize their certain prescriptive nature.

One of the conditions for budgetary reimbursement of partial costs of enterprises in crop production is compulsory crop failure insurance, which places an additional financial burden on agricultural producers and nullifies the financial effect of budget subsidies [21].

In 2018, the total expenditures of the federal budget of the Russian Federation for agro-industrial complex and agriculture amounted to 242.0 billion rubles or less than $1.5 \%$ of the total budget expenditures. In the structure of expenditures of the consolidated budget of the Russian Federation, expenditures on agricultural support in 2018 amounted to 365.8 billion rubles or $1.0 \%$ of total expenditures. Let us analyze the impact of state financial support on the results of profitability of production of certain types of agricultural products.

Table 4. Profitability of products sold by agricultural organizations [19]

\begin{tabular}{|c|c|c|c|c|c|c|c|c|c|}
\hline Years & Grains & $\begin{array}{l}\text { Sunflow } \\
\text { er seeds }\end{array}$ & Sugar beet & $\begin{array}{c}\text { Potato } \\
\text { es }\end{array}$ & $\begin{array}{l}\text { Vegetable } \\
\text { s (in the } \\
\text { open) }\end{array}$ & $\begin{array}{c}\text { Milk and } \\
\text { dairy } \\
\text { products }\end{array}$ & Cattle & Pigs & Eggs \\
\hline \multicolumn{10}{|c|}{ Excluding subsidies from the budget } \\
\hline 2014 & 24.3 & 48.6 & 38.6 & 34.9 & 17.8 & 23.7 & -35.9 & 36.6 & 12.8 \\
\hline 2015 & 39.5 & 90.9 & 78.9 & 23.9 & 26.6 & 19.5 & -27.6 & 28.5 & 17.0 \\
\hline 2016 & 32.8 & 70.5 & 56.2 & 4.7 & 7.4 & 18.5 & -29.9 & 19.7 & 13.5 \\
\hline 2017 & 18.6 & 42.0 & 13.2 & 19.8 & 4.1 & 25.0 & -30.8 & 23.8 & 5.8 \\
\hline 2018 & 25.6 & 33.2 & 27.6 & 22.9 & 12.6 & 14.5 & -30.8 & 35.2 & 9.2 \\
\hline \multicolumn{10}{|c|}{ Including subsidies from the budget } \\
\hline 2014 & 30.5 & 52.8 & 40.5 & 38.2 & 19.5 & 33.0 & -33.0 & 37.3 & 13.6 \\
\hline 2015 & 44.9 & 94.1 & 80.9 & 26.9 & 29.1 & 26.6 & -25.1 & 29.0 & 17.5 \\
\hline 2016 & 37.0 & 73.1 & 58.1 & 5.8 & 9.0 & 28.2 & -27.3 & 19.0 & 5.3 \\
\hline 2017 & 21.4 & 42.2 & 13.4 & 22.3 & 7.5 & 32.3 & -28.7 & 24.1 & 6.6 \\
\hline 2018 & 29.0 & 33.3 & 27.8 & 26.9 & 16.6 & 23.9 & -28.5 & 35.8 & 10.2 \\
\hline
\end{tabular}


The data presented in Table 4 indicate several patterns in the formation of profitability of the agricultural sector of the Russian economy. Firstly, a traditionally high-yield sector is the field of crop production, the level of profitability of products in which is formed on average from 20 to $40 \%$. Secondly, budget subsidies do not fundamentally affect profitability of agricultural producers operating in the field of crop production (where subsidies increase profitability by $2-4 \%$ ). Thirdly, in the field of animal husbandry, activities on raising pigs are practically not subsidized from the budget, which has a consistently high yield of $20-40 \%$. Growing cattle is initially unprofitable and this unprofitability is not compensated even by budget subsidies (loss at the level of $30 \%$ of investments).

\section{DISCUSSION AND CONCLUSIONS}

Analyzing the results of the study, it is necessary to identify a number of features and trends that characterize the financial support of agricultural production in Russia at present:

1. Poor predictability of the financial results of enterprises in the agricultural sector is due not only to natural climatic and biological factors, but also to problems with financing operational activities (dependence on short-term soft loans subsidized by the state).

2. A stable indicator of the share of unprofitable enterprises in agriculture at the level of $25 \%$ does not depend on the annual significant fluctuations in the volumes of the balanced financial result of their activities.

3 . The average level of profitability of agricultural products at the level of $15-20 \%$ differs significantly in the context of the branches of crop production and animal husbandry, which is expressed in low profitability indicators in animal husbandry in comparison with crop production. This trend indicates high risks of enterprises carrying out activities of narrow specialization (only animal breeding) and makes the diversified (combined) nature of conducting agribusiness relevant.

4. In the structure of funding sources of investments in agriculture, an increase in the share and absolute value of borrowed funds is observed, which indicates the insufficiency of own accumulations of agricultural enterprises even in conditions of preferential taxation.

5. The volume of state financial support for the agricultural sector in the Russian Federation is not significant both in the context of the total amount of budget expenditures on agriculture (at the level of $1-1.5 \%$ of the total amount of budget expenditures), and in international comparison. Most government funds are used to subsidize interest rates on short-term loans. Investment needs of the industry are subsidized to a lesser extent.

6. Subsidizing from the budget low-profitable types of activities in agriculture does not compensate for the lossmaking of their activities. At the same time, the state continues to subsidize production of exported highly profitable types of agricultural products.

Given the above trends and contradictions, it is necessary to improve the mechanism of state financial support for agricultural enterprises. There is a number of areas for optimizing the mechanism of state financial support. The budget tools implemented through direct budget subsidies represent the most common form of support for agricultural producers in the world, but have restrictions for WTO member countries. In our opinion, the main criterion of state financial support in the form of budget subsidies should be the export or import orientation of agricultural products. Significant amounts of subsidies should be directed to enterprises engaged in the production of import dependent goods. Subsidizing export-oriented types of agricultural products is justified only when at the same time the company carries out an unprofitable type of activity for import-dependent positions.

The use of credit instruments of state support, the most common in Russian practice, leads to the financial dependence of agricultural producers on expensive borrowed sources of financing.

Regardless of which method of borrowing funds (leasing or credit) is used by agricultural producers, the mechanism of state financial support plays a key role in ensuring external financing of investments in agriculture of the Russian Federation. In this regard, the financial support of leasing from the state is urgently required in order to increase availability of this financial instrument for unprofitable enterprises.

Tax instruments used in Russian practice in the form of preferential taxation of agricultural producers must be optimized taking into account the types of activities in the agricultural sector. Given the varying degrees and frequency of risks in the implementation of current production activities and the implementation of investment projects in crop production, animal husbandry and processing industry, it is advisable to introduce a differentiated approach to establishing tax incentives for these sectors of the agricultural sector.

The subsidies to small businesses in the agricultural sector should also be expanded, as they are not adequately covered by government measures (less than 5\%).

An integrated systematic approach to improving the mechanism of state financial support for agriculture will smooth out intra-industry imbalances, reduce financial risks of agricultural producers and create financial conditions for further development of the industry.

\section{REFERENCES}

[1] V. N. Son, Ch. Schinckus, F. Chong. A post-Marxist approach in development finance: PMF or production mutualisation fund model applied to agriculture // Research in International Business and Finance. Volume 40, April 2017, Pages 94-104.

[2] J.HUANG, Y.WANG. Financing Sustainable Agriculture Under Climate Change, Journal of Integrative Agriculture.Volume 13, Issue 4April 2014, Pages 698-712. 
[13] V.Ya. Uzun. Principles of Formation and Spending of Agricultural Budget in Russia, the USA, Canada and the EU, Economics of agricultural and processing enterprises. - 2015. - No. 2.- pp. 32-41.

[14] Pshikhachev S., Balashenko V., Kalinichenko Ye. The world agribusiness development scenarios at the contracting system: theory and practice, International Journal of advanced studies. - 2015. - Vol.5. - № 4. - p. 43-47.

[15] Narynbaeva A.S., Kaidarova S.E., Baybasheva G.K. Food industry in the system of food security // International University of Kyrgyzstan Herald. - 2015. № 1 (27). - P. 91-95.

[16] Matokh S. Experience of management of state of agricultural production in foreign developed countries, Management problems, 2015, № 1 (54), P. 64-68.

[17] E.E. Zhusipova. Analysis of the Impact of Economic Mechanism to Increase Competitiveness of Enterprises for Agricultural Products and Processed Products in Kazakhstan and Member States of the Customs Union and the Common Economic, Materials of the XI International scientific and practical conference 'Areas of scientific thought' - 2015/2016. - England: Sheffield. - 2015 .- pp.149-152.

[18] C. O’Toole, T. Hennessy. Do decoupled payments affect investment financing constraints? Evidence from Irish agriculture, Food Policy, Volume 56, October 2015 , Pages 67-75.

[19] Agriculture, hunting and hunting sector, forestry in Russia. 2015: Stat.sb., Rosstat. - M., 2015. - 201 p.

[20] Agriculture in Russia, 2019. Federal State Statistics Service of the Russian Federation [Electronic resource]. URL: https://www.gks.ru/ (reference date: 01/19/2020).

[21] Boldyreva I., Andryushchenko, O., Nikitaeva, A., Udalova, Z., Rudash, J. The agricultural production and food industry development trends in the context of food security of Russia, Journal of Environmental Management and Tourism. 2017. T. 8. № 4(20). P.642647.
[11] B.C. Briggeman. Debt, Income and Farm Financial Stress. Main Street Economist, Fed Reserve Publication (2010) (No 6)

[12] M. Petrick, M. Kloss Exposure of EU farmers to the financial crisis Choices, 28 (2) (2013). 